\title{
Worlding Planetary Mine: A viewpoint from Ennore
}

In the very beginning of Arboleda's terrific yet terrifying noir narrative of human-ecological disenchantment resulting from the disturbing material historical conditions of what he refers to as the Planetary Mine is a map charting the destinations of capsize bulk carriers departing from Chilean Ports in 2015. In a context where new methods of cartographic representations and geospatial visualisations play an important role in examining processes of planetary transformation (Katsikis 2018), this map looks deceptively simple. And yet, as it hints at a global economic operation involving supply chains and their elaborate transactions, there is something sinister to it, emptying landscapes of everything other than activities particular to its own purposes of accumulation. As an allusion it is an important juxtaposition to an intertextual reading of Arboleda's monograph for, it is essentially a map of territories of extraction being formed and reshaped under late capitalism. It compels us to think of the planetary mine, Arboleda argues, as not 'a discrete sociotechnical object but a dense network of territorial infrastructures and spatial technologies vastly dispersed across space' (p. 5). While we might not read immediately from the map the concealed histories of organised violence attached to these networked spaces, it prompts us to consider the real-life consequences of the connections shown in the map on human and non-human inhabitants at a planetary scale. More importantly, taking Arboleda's invitation to transcend the territoriality of the mine and its national economic space to explore the plurality of geographies of extraction across the world, this commentary pursues the uncomfortable distribution of the planetary mine, globally tracing one of its circulating lines from the Chilean port of Valparaiso to Ennore in southern India.

Once considered the overseeing port of the Pacific, a bay transformed by sheer stubbornness to become what poet Pablo Neruda described as an absurdity, Valparaiso, literally meaning paradise valley, is located at $33.0472^{\circ} \mathrm{S}, 71.6127^{\circ} \mathrm{W}$, a distance of approximately 10,000 nautical miles from Ennore, situated at $13.2146^{\circ} \mathrm{N}, 80.3203^{\circ} \mathrm{E}$ and involving a shipping journey of anywhere between 30-40 days. ${ }^{1}$ Both are major ports of considerable significance to their country's economic development, serving as crucial nodes for commodities exchange. Orchestrating flows of persons, goods and revenue, they have mobilised extensive infrastructural investments, initially as public undertakings and more recently through

\footnotetext{
${ }^{1}$ This is a rough estimate given by shipping transport websites. Some cite a distance of 12,500 nautical miles taking up to 56 days for the journey.
} 
privatisation models availing a hybrid political-economic order and obscuring a clear sense of political authority (Chalfin 2010). There is a ruthlessness to the way they compete with nearby ports, building and expanding to capture the lucrative promises of global maritime trade. ${ }^{2}$ As such, as Arboleda explains, they are a key component of the planetary mine constituting a technological exoskeleton that extends to multiple resource frontiers. Thus, ports such as Ennore are no longer just a transportation node but complex logistical hubs 'ordering and coordinating circuits of exchange and associated arrangements of control' (Dua 2019: 3). It is also through these chokepoints that we come to witness 'new kinds of crises, new paradigms of security, new uses of law, new logics of killing, and a new map of world' (Cowen 2014: 1).

One among the 12 major ports in India, Ennore Port (officially called Kamarajar Port Ltd.) was initially commissioned in the 1990s to handle thermal coal for Tamil Nadu Generation and Distribution Corporation Limited (TANGEDCO). Operationalised in 2001 as India's first and only corporate port, Ennore's ambitions have gone beyond simply functioning as a coalberthing station serving Thermal Power Plants in the vicinity to include a Container Terminal privately operated by Adani Ports and SEZ Ltd. As a multi-purpose cargo terminal, Ennore is now well-equipped to handle not just coal, but all kinds of dry, bulk and project cargos. These expansions suggest a new paradigm of 'logistical urbanisation', one that Arboleda describes as 'a new rubric of microspatial infrastructural planning and territorial design that revolves around speed, continuity, and connectivity, and where city and noncity space are cast in relational terms' (p. 32). Here, Ennore exemplifies what Brenner and Katsikis (2020) refer to as 'the hinterland question' where it is no longer simply Chennai's industrial hinterland, its constitutive outside co-opted by its maelstrom of urbanisation but an operational landscape requiring a larger-scale process of infrastructural configuration and territorial reorganisation. Emphasising a land use logic that is less about the industrial or agrarian, it is more focussed on the extractive, extending its adverse effect over its ecologies - terrestrial, oceanic, subterranean and atmospheric.

It is this latter aspect that compels us to reconsider Ennore's material landscape, one that has little to do with the construction of factories or ports and their supporting infrastructure of roads,

\footnotetext{
${ }^{2}$ In the case of Ennore, it is located in close proximity to Chennai and Kattupalli Ports. Maersk Line which accounts for 20 percent of India's container freight, for instance, recently revised its inter-Asia route to call at Ennore instead of Chennai due to chronic congestion concerns at the latter.
} 
railways, bridges, breakwaters, warehouses, deep-water berths, quays and what not, but reaching back to its etymological history when Ennore's place-based toponym was associated with a creek and not the recurrent topos of an industrial backwater. ${ }^{3}$ Even though the creek itself is only $400 \mathrm{~m}$ wide, stretching $3 \mathrm{~km}$ into the sea and $5 \mathrm{~km}$ along the coast, its ontological consciousness derives from a sensitive estuarine ecosystem, draining two important rivers, Koassthalaiyar in the South and Aranaiyar in the North into the Bay of Bengal. In addition, Pulicat Lake, the second largest brackish water lake in the country also drains into the creek. Dotted with salt pans, mangroves, marshes, mudflats and fish farms, over the years the creek's ecosystem has been continuously eroded by all forms of anthropogenic assault. The seasonal nature of the creek's interconnected ecological features suggest a natural ecosystem that is unpredictable, and yet has been the (socio-economic) mainstay of fishing communities living in its environs, forging human and more-than-human identities that cannot be reduced to a pure environmental aesthetic. It is perhaps due to this lack of a tantalising imaginary that the relentless unmaking of the creek's ecology by Ennore's industrial infrastructure went unnoticed for several years. More recently, its ecological damage has blown into a full-fledged conflict over livelihood losses as communities and environmental activists together tackle the fissures caused by its longer history of land expropriation, class, caste and gender hierarchies as well as exclusionary forms of labour dynamics. ${ }^{4}$

Through a tactical deployment of 'slow activism' (Robins 2014) and its politics of the ordinary, local fishing communities and activists bring their environmental subjectivity to the foreground of a rising ecological awareness, confronting squarely the challenge of reimagining the creek's ecology over and above Ennore's man-made infrastructure. Here, it is not just about personalising the narrative through their own sense of (economic) loss, but also building on significant scientific knowledge about the destruction of Ennore's ecology due to erosion and accretion caused by port construction as well as all-around discharge of industrial pollutants. ${ }^{5}$ However, if we are to paraphrase Scaramelli (2019), places such as Ennore articulate a moral stance on the estuarine worlds of infrastructures and ecologies, both entangled and inseparable,

\footnotetext{
${ }^{3}$ Ennore or Enūr literally means my place.

${ }^{4} \mathrm{See}$ https://storyofennore.wordpress.com/ which is a website/blog reclaiming rights, livelihoods and ecosystems around the Ennore Creek.

${ }^{5}$ There is clear evidence of shoreline erosion and accretion due to the breakwaters which is also causing closure of the Ennore Creek mouth alongside affecting the wave energy in the region. This mouth has to be kept open for water intake to the coolant system of the Thermal Power Pant necessitating an uninterrupted dredging activity by TANGEDCO.
} 
triggering possible assessments of justice and motivations for action. There is a rather provocative argument to be made here that any reimagination of the creek's ecology has to take place not outside of the infrastructure but within it. Thus, as coal remains the primary object of circulation at the port, it is through its materiality, particularly its discards that the ecological failure of Ennore has come to be vividly registered. Fly ash, in this context, emerges as a tangible proof of the way infrastructure and ecology are enmeshed in this estuarine world. As a globally synchronous Anthropocene marker (Rose 2015), fly ash is coal's afterlife, manipulating life in the air, in the soil, surfaces beneath and surfaces above (Bhat 2018). Emerging as a toxic discourse in Ennore fly ash points to an exigency that is more than a rhetoric (Buell 1998), a reminder of Ennore's putative failures as a 'lively infrastructure'.

But as we strive to visualise the real life consequences of the planetary mine on places like Ennore, there is a ubiquitous gloom to its bleak dystopian world of abandoned presents and unwanted futures (Robinson 2010). Many of the struggles are mired in a certain pessimism that close off any sense of a politics of possibility which is essential if we are to use Ennore's insurgence to recover its multiplicity, complexity and co-existing temporalities (ibid.). It is this alternative form of futurism placing hopefulness in the creative potential of cities that we see in the quirky rendering of famed Tamil classical musician TM Krishna's Chennai Porombokku Paadal where he draws our attention to not only Ennore's ecological abuse but also disrupt narratives of the landscape as a 'wasteland' emplacing it instead with new meanings. ${ }^{6}$ Complimenting this storytelling culture is the emergence of the subaltern as a more than enchanted figure, that far from being sublime restores Ennore's toponymic heritage through a vernacular knowledge tracking environmental change and reconstructing past land use. Such situated visualisations contest an established mode of representation attached to a planetary assertion of power relations. You see this when, despite $25 \mathrm{~km} 2$ declared as a tidal water body by the Coastal Regulation Zone-1 notification, much of the creek has vanished in records and official narratives through a deliberate politics of erasure, prompting historian Bhavani Raman's (2020: 54) comment on the curious disappearance of the Ennore Creek: '[b]efore landscapes die, they first vanish in the imagination'.

\footnotetext{
${ }^{6} \mathrm{https}: / /$ www.youtube.com/watch?v=82jFyeV5AHM 
Using an oral tradition that unravels a sedimentation of stories, a palimpsest of memory and a particular archaeology of territorialisation provides a powerful counternarrative to contemporary scholarly research that can find itself limited by the mono-cultural imaginary of the Anthropocene (Hayman 2018). Thus, Krishna's song finds a 'pirate aesthetic' in Ennore as a wasteland reimagined, collating an archival present of sounds, images and disturbing countermemories of new publics and cultural worlds of subaltern populations (Sundaram 2010). The questions raised by such struggles in the midst of uncertainty make their resistance come across as a worlding practice (Ong 2011), entailing a specific, categorical outlook of the planetary through an open-ended vitalism. It is through these creative forms of subaltern struggles that we see a worlding that is simultaneously attentive to the semantics of both planetary and subaltern thinking in the Anthropocene (Tella 2019).

\section{Conclusion}

In its award-winning installation Tectonic Resonances for the 2021 London Design Biennale, the Chilean pavilion constructs an acoustic curation of lithophones from quarries, deserts and the Andean mountains to remind us that rocks resound, whether it is through earthquakes or blasting for mineral extraction. ${ }^{7}$ The exhibit recreates the Andes as a geological event, using the sonorous experience of the lithophone to think about the consequences of the Anthropocene. Such creative interventions provide a new kind of provenance for understanding the planetary mine perhaps as a hyperobject, in Morton's sense (2013), not just for its extensive distribution but for its pervasive and discursive ability to register anxieties about the resurgence of capitalism, conservatism and militarism on the global stage. Coming across as something fantastical, the study of something as widely extended as the planetary mine poses challenging methodological questions demanding critical reflection on our limits of knowing. Thus, even as 'ordinary' places such as Ennore show that they are never simply local or entirely contained, they become critical sites to think with and broaden the terraqueous analytic of Anthropocene ecologies. It is thus important that we establish the contingent and relational nature of the planetary mine, exposing its ontological instability as processual and emergent. This allows it to be tackled as a real proposition, one that is objectively empirical. Otherwise, despite the best efforts of scholarship such as Arboleda's, the planetary mine might be widely recognised but risks being poorly understood.

\footnotetext{
${ }^{7}$ https://www.londondesignbiennale.com/participant/chile-0 
References:

Bhat, H. (2018). "Over skies of extraction." Lo Squaderno - Explorations in Space and Society 48: $23-26$

Buell, L. (1998). "Toxic discourse." Critical Inquiry 24(Spring): 639-665.

Chalfin, B. (2010). "Recasting maritime governance in Ghana: The neo-developmental state and the Port of Tema." The Journal of Modern African Studies 48(4): 573-598.

Cowen, D. (2014). The deadly life of logistics: Mapping violence in global trade. Minneapolis, University of Minnesota Press.

Dua, J. (2020). "Amergris, livestock and oil: Port-making and chokepoint making in the Red Sea." Ethnos DOI: 10.1080/00141844.2019.1696861.

Hayman, E. (2018). "Future rivers of the Anthropocene or whose Anthropocene is it? Decolonising the Anthropocene!" Decolonization: Indigeneity, Education \& Society 6(2): 77 92.

Katsikis, N. (2018). Visualizing the planetary urban. Doing Global Urban Research. J. Harrison and M. Hoyler, SAGE: 12-33.

Katsikis, N. and N. Brenner (2020). "Operational landscapes: Hinterlands of the Capitalocene." Architectural Design 90(1): 22-31.

Morton, T. (2013). Hyperobjects: Philosophy and ecology after the end of the world. Minneapolis, University of Minnesota Press.

Ong, A. (2011). Introduction: Worlding cities, or the art of being global. Worlding cities: Asian experiments and the art of being global. A. Ong and A. Roy, Wiley-Blackwell: 1-26.

Raman, B. (2020). The curious disappearance of the Ennore Creek. The botanical city. M. Gandy and S. Jasper. Berlin, Jovis: 54-61.

Robins, S. (2014). "The 2011 toilet wars in South Africa: Justice and transition between the exceptional and the everyday after Apartheid." Development and Change 45(3): 479-501.

Robinson, J. (2010). Living in dystopia. Noir urbanism. G. Prakash. Princeton, Princeton University Press: 218-240.

Rose, N. L. (2015). "Spheroidal Carbonaceous Fly Ash Particles Provide a Globally Synchronous Stratigraphic Marker for the Anthropocene." Environmental Science \& Technology 49(7): 4155-4162.

Scaramelli, C. (2019). "The delta is dead: Moral ecologies of infrastructure in Turkey." Cultural Anthropology 34(3): 388-416. 
Sundaram, R. (2010). Imaging urban breakdown. Noir urbanism. G. Prakash. Princeton, Princeton University Press: 241-260.

Tella, R. K. (2020). "Crisis, constitutionalism and the geographies of belonging: Indian ecopolitics in the Anthropocene." Journal of the Indian Ocean Region 16(1): 63-78. 